\title{
Recurrent late-onset fibrotic capsular block syndrome after neodymium-yttrium- aluminum-garnet laser anterior capsulotomy: a case report
}

\author{
Joong Sik Koh', Young Bin Song ${ }^{2}$, Won Ryang Wee ${ }^{1}$ and Young Keun Han ${ }^{1,2^{*}}$
}

\begin{abstract}
Background: Capsular block syndrome is an uncommon complication that occurs after cataract surgery. It is characterized by capsular distension, anterior intraocular lens displacement, anterior chamber shallowing, and unexpected myopic shifts. We report a case of recurrent fibrotic capsular block syndrome with Elschnig's pearl-type posterior capsule opacification 10 months after neodymium-yttrium-aluminum-garnet (Nd:YAG) laser anterior capsulotomy.

Case presentation: A 72-year-old Asian man complained of decreased visual acuity 5 years after undergoing phacoemulsification with posterior chamber lens implantation. Under slit-lamp examination, late postoperative capsular block syndrome was diagnosed and Nd:YAG laser anterior capsulotomy was performed. Ten months after anterior capsulotomy, the patient returned with decreased visual acuity and was diagnosed with recurrent fibrotic capsular block syndrome. Nd:YAG laser posterior capsulotomy was performed.
\end{abstract}

Conclusions: We found that fibrotic capsular block syndrome could recur with Elschnig's pearl-type posterior capsule opacification after Nd:YAG laser anterior capsulotomy for late postoperative capsular block syndrome without posterior capsule opacification.

Keywords: Capsular bag distension, Capsular block syndrome, Cataract surgery, Neodymium-yttrium-aluminum-garnet laser posterior capsulotomy

\section{Background}

Capsular block syndrome (CBS) is a rare complication that occurs after cataract surgery. It develops when the continuous curvilinear capsulorhexis (CCC) margin is occluded by the intraocular lens (IOL) optic [1]. This complication is characterized by distension of the capsular bag and accumulation of a liquefied substance inside the capsular bag [2]. Kim and Shin [2] classified CBS as either non-cellular, inflammatory, or fibrotic, according to clinical characteristics. Non-cellular CBS develops within a day after surgery and is caused by an

\footnotetext{
* Correspondence: eye129@paran.com

'Department of Ophthalmology, Seoul National University College of

Medicine, \#101 Daehang-roJongno-gu, Seoul 110-744, Korea

${ }^{2}$ Department of Ophthalmology, Seoul Metropolitan Government-Seoul

National University Boramae Medical Center, \#20 Boramae-ro

5-gilDongjak-gu, Seoul 156-707, Korea
}

ophthalmic viscosurgical device. Inflammatory CBS develops several days after surgery and is caused by an inflammatory reaction. Fibrotic CBS develops several months to years after surgery and is characterized by fibrosis over the entire circumference of the anterior capsule opening and posterior capsule opacification (PCO). Herein, we report a case of recurrent fibrotic CBS with Elschnig's pearl-type PCO that occurred 10 months after neodymium-yttrium-aluminum-garnet (Nd:YAG) laser anterior capsulotomy, which is normally performed for inflammatory-like CBS without PCO or fibrosis.

\section{Case presentation}

In July 2007, a 67-year-old man with an age-related cataract in his left eye underwent uneventful phacoemulsification with implantation of an Akreos Adapt posterior 
chamber intraocular lens (Bausch \& Lomb, Rochester, NY, USA) in the capsular bag under Healon GV (Abbott Laboratories, Abbott Park, IL, USA). Phacoemulsification was performed through a temporal clear corneal incision, and there were no postoperative complications. One month after the operation, his uncorrected visual acuity (UCVA) was $20 / 30$ with $-0.5 \mathrm{D} \mathrm{SPH}=-1.25 \mathrm{D}$ CYL $\times 60^{\prime}$. Three years after surgery, his UCVA was $20 /$ 20 with $-0.75 \mathrm{D} \mathrm{SPH}=-1.00 \mathrm{D} \mathrm{CYL} \times 70^{\prime}$. The anterior chamber was deep and the IOL was well-positioned within the capsular bag.

In December 2011, the patient presented with decreased visual acuity of 20/100 with $-2.75 \mathrm{D}$ SPH $=$ $-2.25 \mathrm{D} \mathrm{CYL} \times 70^{\prime}$, and his intraocular pressure (IOP) was $9.0 \mathrm{mmHg}$. Slit lamp biomicroscopic examination revealed a circumferential occlusion between the margin of the anterior capsule opening and the anterior surface of the peripheral IOL optic. There was a pool of turbid, milky-white fluid between the forward-displaced IOL and the posterior capsule. The posterior capsule was vaulted posteriorly, yet there was no PCO (Figs. 1 and 2). No cell or flare was observed in the anterior chamber, and no abnormalities were observed in the cornea, vitreous body, or retina. Capsular block syndrome was diagnosed, and posterior capsulotomy was scheduled to remove the substance. However, the Nd:YAG laser aiming beam could not be focused on the posterior capsule because of the intense opacity of the contents in the hyperdistended capsular bag. Alternatively, anterior capsulotomy was performed beyond the 6-o'clock edge of the IOL with an Nd:YAG laser (Fig. 3). A turbid fluid with minute white cells was emptied from the capsular bag anteriorly into the anterior chamber, and the distended capsule was restored (Fig. 4). One week after the procedure, the patient's UCVA improved to 20/30 with

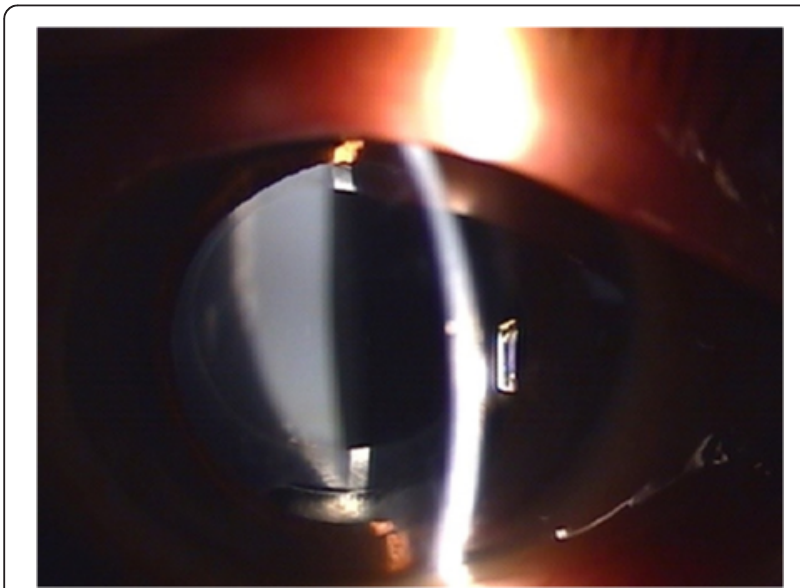

Fig. 1 Slit lamp examination shows a milky-white substance accumulated behind the intraocular lens and posterior capsular bag distension

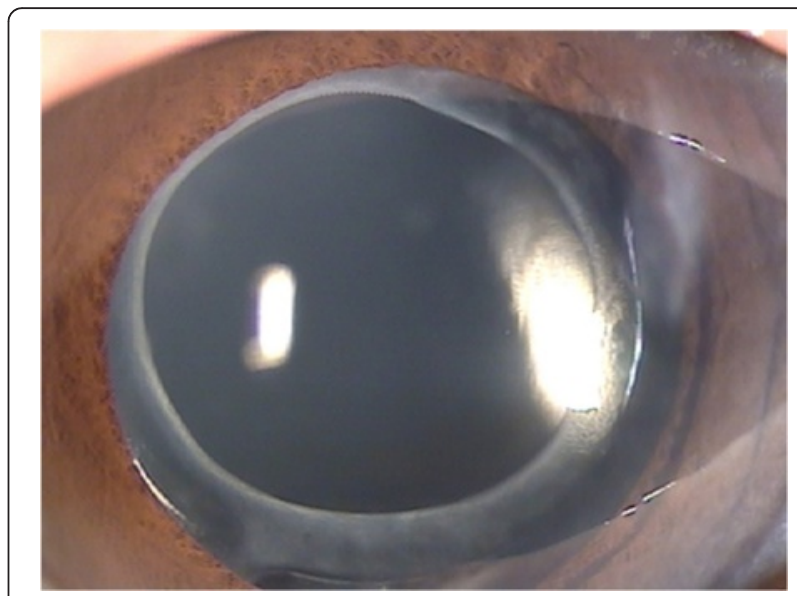

Fig. 2 Slit lamp examination shows milky-white substance accumulation without capsular fibrosis at the first occurrence of capsular block syndrome

$-1.00 \mathrm{D} \mathrm{SPH}=-1.50 \mathrm{D} \mathrm{CYL} \times 70^{\prime}$, and his IOP was $7.0 \mathrm{mmHg}$.

Ten months after anterior capsulotomy, the patient returned with decreased visual acuity. His uncorrected visual acuity was $20 / 50$ with $-3.5 \mathrm{D} \mathrm{SPH}=-2.75 \mathrm{D}$ $\mathrm{CYL} \times 20^{\prime}$, and his IOP was $9.0 \mathrm{mmHg}$. Posterior capsular distension was observed with clear fluid in the bag. Elschnig's pearl-type PCO and fibrosis along the entire capsule opening with clogging of the anterior capsulotomy opening were present. The patient was diagnosed with recurrent fibrotic capsular block syndrome, and Nd:YAG posterior capsulotomy was performed immediately. Posterior capsular opacity and fluid were emptied from the capsular bag posteriorly into the vitreous after the procedure, and the distended capsule was restored (Fig. 5). One week after the operation, his UCVA improved to $20 / 30$ with $-0.75 \mathrm{D} \mathrm{SPH}=-1.75 \mathrm{D} \mathrm{CYL} \times 68^{\prime}$, and his IOP was $10.0 \mathrm{mmHg}$.

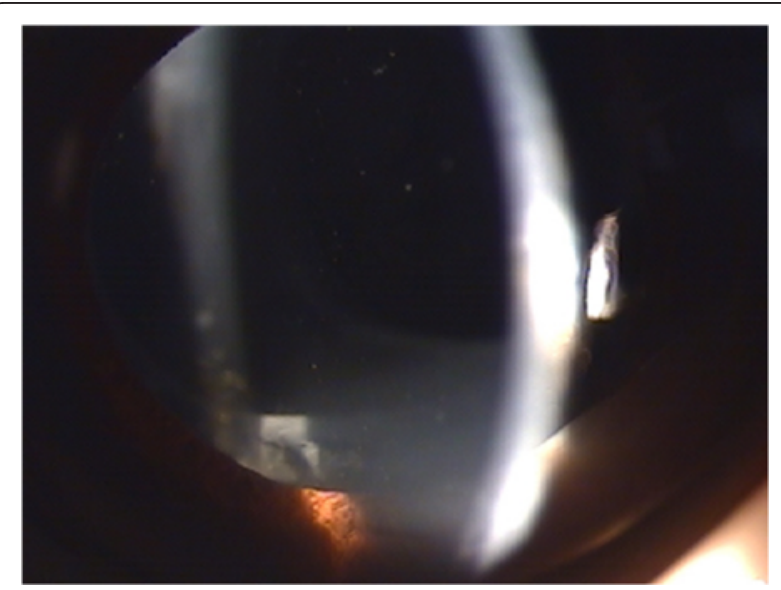

Fig. 3 Six-o'clock Nd:YAG laser anterior capsulotomy was performed 


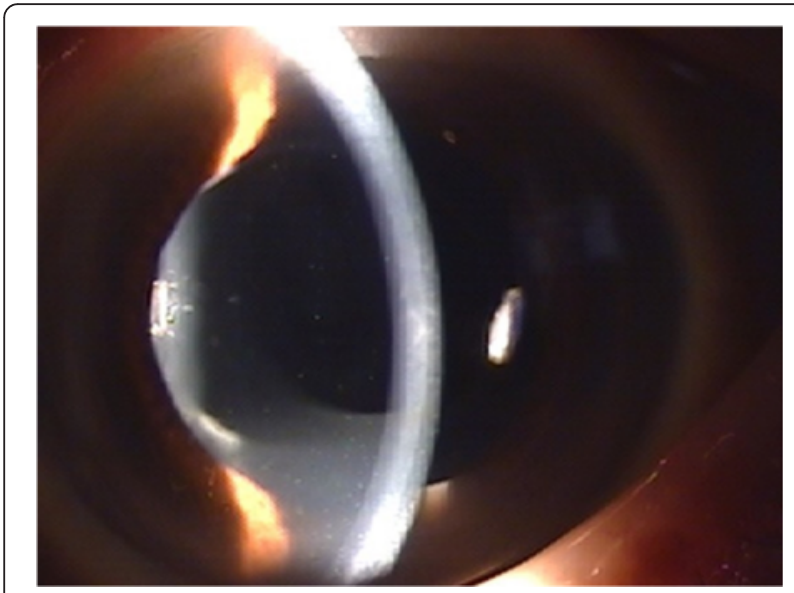

Fig. 4 After Nd:YAG laser anterior capsulotomy, the milky-white fluid was emptied from the capsular bag into the anterior chamber, and the distended capsular bag was collapsed

\section{Conclusions}

Capsular block syndrome is an uncommon complication that occurs with posterior chamber, in-the-bag IOL implantation and CCC [3-5]. It was first described by Davison [3] as an early postoperative complication. Since then, other researchers have reported that CBS usually occurs during the early postoperative period; however, it can also occur during the late postoperative period [68]. Miyake et al. [9] classified CBS as intraoperative, early postoperative, and late postoperative. Late postoperative CBS may also be asymptomatic or undetected prior to development of PCO [10]. Late postoperative CBS occurs less frequently and has yet to be confirmed definitively.

According to the clinical characteristics described by Kim and Shin, postoperative CBS can be divided into

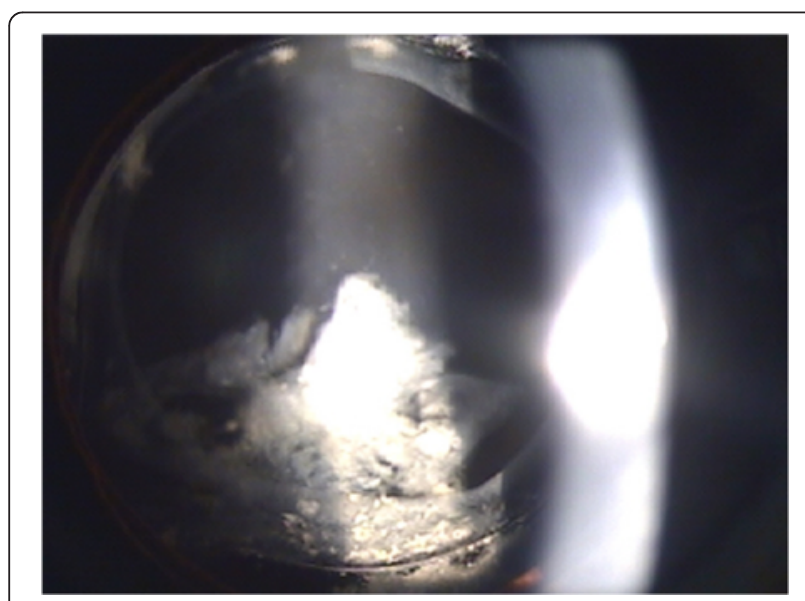

Fig. 5 Slit lamp examination shows removed posterior capsule opacity and resolved capsular block syndrome following $\mathrm{Nd}$ :YAG laser posterior capsulotomy three types: non-cellular (1 day after surgery; presents with a shallow anterior chamber and an anteriorly displaced IOL), inflammatory (several days after surgery; presents with distended capsular bag and inflammatory reaction), and fibrotic (late postoperative period; presents with circumferentially anterior capsule fibrosis and posterior capsule opacification) [2]. In our case, CBS with a turbid, milky-white fluid without capsular fibrosis was found in the first onset of CBS. It was neither noncellular nor fibrotic; therefore, it was classified as a similar type of inflammatory CBS, despite no evidence of inflammation. Additionally, 10 months after anterior capsulotomy, there was fibrosis along the entire capsule opening and Elschnig's pearl-type PCO. This led to the obvious conclusion of fibrotic CBS.

Clinically, CBS is characterized by capsular distension, anterior IOL displacement, anterior chamber shallowing, and unexpected myopic shifts. Reasons for myopic shift in CBS are multifactorial. Forward IOL displacement and possibly higher refractive indices of opalescent materials, compared with those of the IOL and vitreous humor, will move retinal images more anteriorly, thereby resulting in a myopic shift. Additionally, the enlarged space that fills with opalescent materials may act as either a phakic IOL or a piggyback IOL; this will also increase convergent power [11]. Other researchers have found that myopic shifts were not exhibited in late postoperative CBS [8, 12]. Bao et al. [7] showed that high resistance, induced by rigid fibrosis of the capsule, may prevent the IOL from being pushed forward and subsequent distension of the capsular bag. In our case, the myopic shift at the first onset of CBS can be explained by a forward-displaced IOL, increased convergent power due to opalescent materials, and no rigid fibrotic change. However, we also found myopic shifts in the recurrent fibrotic CBS with PCO. We think that this was caused by two different factors: (1) the previously distended anterior capsular may have had potential laxity to IOL anterior shifting and (2) Elschnig's pearl-type PCO acting as a convex lens may have occurred during the myopic shift.

While some cases of early postoperative CBS can be resolved spontaneously within the first month, Nd:YAG anterior capsulotomy and posterior capsulotomy were suggested as treatment options for CBS [13]. Durak et al. [13] reported success rates for anterior capsulotomy (50 \%, 5 of 10 eyes) and posterior capsulotomy (100\%, 5 of 5 eyes). According to this report, posterior capsulotomy, rather than anterior capsulotomy, is the recommended form of treatment; however, anterior capsulotomy is simpler, and there are times when posterior capsulotomy is not feasible owing to technical reasons [14].

In this case, we performed Nd:YAG laser anterior capsulotomy. It is difficult to focus on the posterior capsule 
while performing Nd:YAG laser posterior capsulotomy for late-onset CBS without PCO because of the opacity of the capsular bag contents and IOL vaulting. Furthermore, some people complain of floaters [15], and other complications, such as cystoid macular edema, severe inflammation, increased intraocular pressure or retinal detachment, have been reported after Nd:YAG laser posterior capsulotomy [16]. In some reports, Nd:YAG laser anterior capsulotomy was chosen as the primary treatment for late postoperative CBS $[4,13,15]$. We prefer anterior capsulotomy as a first line treatment for late-onset CBS without PCO. When PCO is present, we prefer to perform posterior capsulotomy. If posterior capsulotomy is not feasible owing to technical reasons, anterior capsulotomy followed by immediate laser posterior capsulotomy can be an alternative treatment.

The entrapped liquid in the capsular bag of patients with CBS has been biochemically analyzed. Suguira et al. [17] reported that sodium hyaluronate was the main component of the transparent liquid in the capsular bag in a case of early postoperative CBS. Namba et al. [18] detected a high protein concentration (primarily human serum albumin with small amounts of globulin fractions) in the milky-white fluid from two patients. Bao et al. [7] analyzed 6 years' worth of passing milky-white liquid from patients with late postoperative CBS and reported that concentrations of $\mathrm{Ca}^{2+}$ and proteins proved to be crystals and crystalline peptides. These materials are thought to be elicited from residual lens epithelial cells (LECs), to increase osmotic pressure inside the capsular bag, and to cause greater liquid accumulation [5, 9]. However, it is unclear what factors lead to stimulation of residual LECs.

Although Kim and Shin [2] suggested that inflammatory CBS developed several days after surgery, our similar case of CBS without capsular fibrosis developed 4 years after surgery. This can explain how inflammatory CBS enables either late onset or slow progression. In this enclosed, stable condition, residual LECs are protected from metaplasia and proliferation. However, after anterior capsulotomy, we found fibrotic CBS with Elschnig's pearl-type PCO. There was either LEC proliferation or anterior capsule fibrosis clogging the anterior capsulotomy opening; this led to a recurrence of fibrotic CBS. We found that if there were changes in lens capsular cavity, such as an interaction between aqueous humor and the capsular bag after anterior capsulotomy, LECs can be stimulated to metaplasia and proliferation. During our literature review, we found that Elschnig's pearltype PCO can occur when LECs are stimulated by the aqueous humor [19, 20]. For example, Elschnig's pearltype LECs have been known to proliferate from the adsorption of some extracellular matrix proteins in the aqueous humor $[19,20]$. Despite this, we are unsure what kinds of substances were associated with our case. In our experience, intraoperative removal of LECs with complete cortex removal and capsule polishing is important in order to protect against CBS recurrence. Additionally, regular follow-up and re-evaluation of these patients are needed.

On the basis of this case, we found that fibrotic CBS and Elschnig's pearl-type PCO could recur after Nd:YAG laser anterior capsulotomy for late postoperative CBS without PCO. To our knowledge, this is the first report of recurrent fibrotic CBS with Elschnig's pearl-type PCO after Nd:YAG laser anterior capsulotomy.

\section{Abbreviations}

CBS, capsular block syndrome; CCC, continuous curvilinear capsulorhexis; IOL, intraocular lens; IOP, intraocular pressure; LECs, lens epithelial cells; Nd:YAG, neodymium-yttrium-aluminum-garnet; PCO, posterior capsule opacification; UCVA, uncorrected visual acuity

\section{Acknowledgements}

The authors would like to thank all staff involved in the care of the patient presented in this case report.

\section{Funding}

No funding was received by any of the authors for the writing of this manuscript.

Availability of data and materials

All the data supporting the findings is contained within the manuscript.

\section{Authors' contributions}

JSK and YBS contributed to the literature search and preparation of the manuscript and figures. WRW provided critical revision. YKH was responsible for the clinical management of the patient and the design of the case report. All authors read and approved the final manuscript.

\section{Competing interests}

The authors declare that they have no competing interests.

\section{Consent for publication}

Written informed consent was obtained from the patient for publication of this case report and any accompanying images. A copy of the consent is available for review by the Editor of this journal.

Ethics and consent to participate

Ethical approval was not required as this manuscript presents a case study.

Received: 16 November 2015 Accepted: 28 May 2016

Published online: 11 June 2016

\section{References}

1. Shah NA, Goulstine DB. Capsular block syndrome presenting with a hyperopic shift. J Cataract Refract Surg. 2006;32:1974-6.

2. Kim HK, Shin JP. Capsular block syndrome after cataract surgery: clinical analysis and classification. J Cataract Refract Surg. 2008;34:357-63.

3. Davison JA. Capsular bag distension after endophacoemulsification and posterior chamber intraocular lens implantation. J Cataract Refract Surg. 1990;16:99-108.

4. Holtz SJ. Postoperative capsular bag distension. J Cataract Refract Surg. 1992;18:310-7.

5. Theng JT, Jap A, Chee SP. Capsular block syndrome: a case series. J Cataract Refract Surg. 2000;26:462-7.

6. Choi BJ, Jin YB, Hur J. Postoperative capsular bag distension in cataract surgery. J Korean Ophthalmol Soc. 1998;39:2031-7.

7. Bao YZ, Pei XT, Li MW, Li XX. Late postoperative capsular block syndrome versus liquefied after-cataract. J Cataract Refract Surg. 2008;34:1799-802. 
8. Patil S, Azarbod P, Toufeeq A. Late-onset capsular block syndrome without lens displacement. Eye (Lond). 2007;21:113-4.

9. Miyake K, Ota I, Miyake S, Horiguchi M. Liquefied aftercataract: a complication of continuous curvilinear capsulorhexis and intraocular lens implantation in the lens capsule. Am J Ophthalmol. 1998;125:429-35.

10. Pinarci EY, Bayar SA, Sizmaz S, Canan H, Yilmaz G. Late capsular block syndrome presenting with posterior capsule opacification. J Cataract Refract Surg. 2012;38:672-6.

11. Masket S. Consultation section: cataract surgery problems. J Cataract Refract Surg. 2002;28:2073-9.

12. Qu J, Bao Y, Li M, Zhao M, Li X. Surgical management of late capsular block syndrome. J Cataract Refract Surg. 2010;36:1687-91.

13. Durak I, Ozbek Z, Ferliel ST, Oner FH, Söylev M. Early postoperative capsular block syndrome. J Cataract Refract Surg. 2001;27:555-9.

14. Colakoglu A, Kucukakyuz N, Topcuoglu IE, Akar S. Intraocular pressure rise and recurrence of capsular block syndrome after neodymium: YAG laser anterior capsulotomy. J Cataract Refract Surg. 2007;33:1344-6.

15. Yang MK, Wee WR, Kwon JW, Han YK. Anterior chamber depth and refractive change in late postoperative capsular bag distension syndrome: a retrospective analysis. PLoS One. 2015;10:e0125895.

16. Steinert RF, Puliafito CA, Kumar SR, Dudak SD, Patel S. Cystoid macular edema, retinal detachment, and glaucoma after Nd:YAG laser posterior capsulotomy. Am J Ophthalmol. 1991;112:373-80.

17. Sugiura T, Miyauchi S, Eguchi S, Obata H, Nanba H, Fujino Y, et al. Analysis of liquid accumulated in the distended capsular bag in early postoperative capsular block syndrome. J Cataract Refract Surg. 2000;26:420-5.

18. Namba H, Namba R, Sugiura T, Miyauchi S. Accumulation of milky fluid: a late complication of cataract surgery. J Cataract Refract Surg. 1999;25:1019-23.

19. Konno K, Nagamoto T. Membranous proliferation on the posterior surface of an intraocular lens after Nd: YAG laser capsulotomy. Jpn J Ophthalmol. 2005; $49: 173-5$

20. Nagamoto T, Hara E. Postoperative membranous proliferation from the anterior capsulotomy margin onto the intraocular lens optic. J Cataract Refract Surg. 1995;21:208-11.

\section{Submit your next manuscript to BioMed Central and we will help you at every step:}

- We accept pre-submission inquiries

- Our selector tool helps you to find the most relevant journal

- We provide round the clock customer support

- Convenient online submission

- Thorough peer review

- Inclusion in PubMed and all major indexing services

- Maximum visibility for your research

Submit your manuscript at www.biomedcentral.com/submit

C Biomed Central 